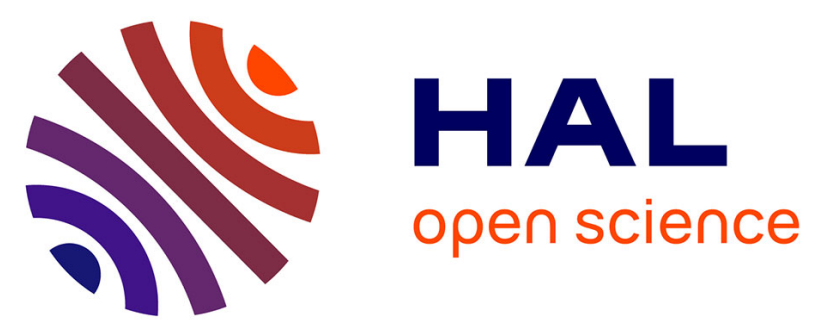

\title{
Optimization of cadmium ions biosorption by fish scale from aqueous solutions using factorial design analysis and Monte Carlo simulation studies
}

\author{
Amine Jaafar, A. Darchen, S.E. Hamzi, Z. Lakbaibi, A. Driouich, A. \\ Boussaoud, A. Yaacoubi, M. El Makhfouk, M. Hachkar
}

\section{To cite this version:}

Amine Jaafar, A. Darchen, S.E. Hamzi, Z. Lakbaibi, A. Driouich, et al.. Optimization of cadmium ions biosorption by fish scale from aqueous solutions using factorial design analysis and Monte Carlo simulation studies. Journal of Environmental Chemical Engineering, 2021, 9 (1), pp.104727. 10.1016/j.jece.2020.104727 . hal-03157951

\section{HAL Id: hal-03157951 \\ https://hal.science/hal-03157951}

Submitted on 8 Mar 2021

HAL is a multi-disciplinary open access archive for the deposit and dissemination of scientific research documents, whether they are published or not. The documents may come from teaching and research institutions in France or abroad, or from public or private research centers.
L'archive ouverte pluridisciplinaire HAL, est destinée au dépôt et à la diffusion de documents scientifiques de niveau recherche, publiés ou non, émanant des établissements d'enseignement et de recherche français ou étrangers, des laboratoires publics ou privés. 


\section{Optimization of cadmium ions biosorption by fish scale from aqueous solutions using} factorial design analysis and Monte Carlo simulation studies

Adil Jaafara,b*, André Darchenc, Said El Hamzib,d, Zouhair Lakbaibie, Anas Driouichf, Abdelghani Boussaoud ${ }^{\mathrm{b}}$, Abdelrani Yaacoubi $^{\mathrm{d}}$, El Makhfouk Mohammed ${ }^{\mathrm{b}}$, Mohsine Hachkarb

${ }^{a}$ Higher School of Education and Training, Berrechid, Hassan First University, Settat, Morocco

${ }^{b}$ Laboratory of Process, Signals, Industrial Systems, Computer Science, Superior School of Technology, Cadi Ayyad University, Dar Si-Aïssa road, 46000, BP 89, Safi, Morocco cUMR CNRS n6226 - Institut des Sciences Chimiques de Rennes, ENSCR, 11 Allée de Beaulieu - CS 50837 - 35708 Rennes Cedex 7, France

${ }^{d}$ Laboratory of Applied Chemistry, Unity of Methodology and Environment, Faculty of

Sciences Semlalia, Cadi Ayyad University, B.P 2390 Marrakech, Morocco

${ }^{e}$ Laboratory of Natural Substances and Synthesis and Molecular Dynamics, Faculty of Sciences and Techniques, 52000, Moulay Ismail University, Errachidia, Morocco

${ }^{f}$ Laboratory of chemical engineering and environment, Faculty of Sciences and

Technology, Hassan II University, Mohammedia, Morocco

* Corresponding author.

E-mail address:jaafarfstgm@gmail.com (A.Jaafar).

Graphical abstract

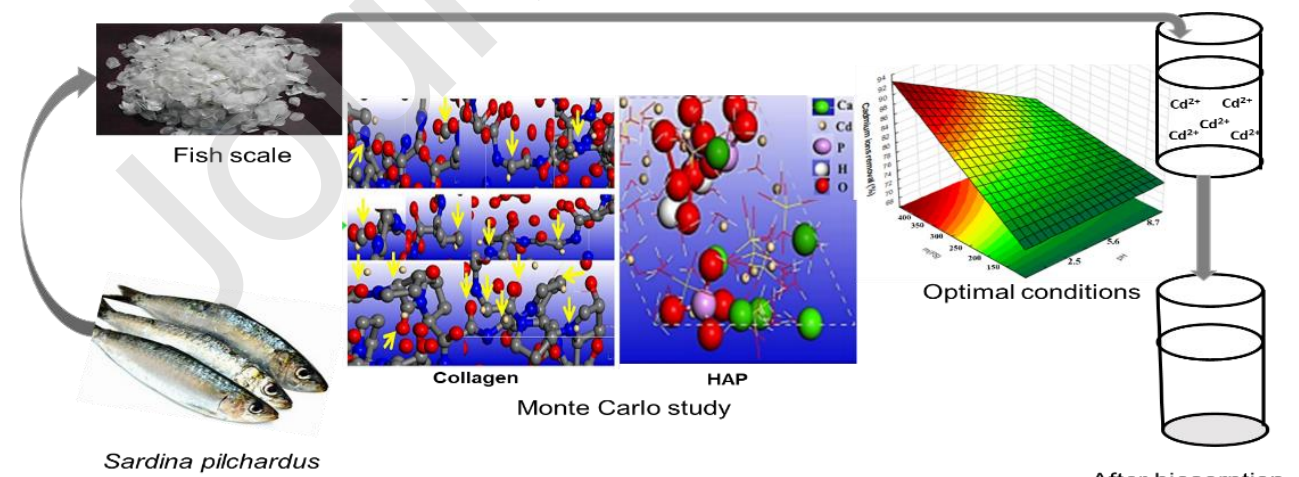

After biosorption

\section{Highlights}


- Fish scales of Sardina pilchardus was used as biosorbent in the removal of $\mathrm{Cd}(\mathrm{II})$

- The biosorption capacity of the biosorbent for Cadmium ions was $52.08 \mathrm{mg} \mathrm{g}^{-1}$

- The parameters were analyzed and optimized using full factorial design methodology

- Pseudo-second order kinetics and Langmuir isotherm model gave the best fit

- The sorption of Cd(II) onto Fish scale was studied by a Monte Carlo simulation 


\section{ABSTRACT}

This work investigated cadmium ions biosorption on Fish scales (FS) of Sardina pilchardus. Different relevant parameters such as initial $\mathrm{pH}$ in the range $2.14-7.76$, initial cadmium concentration from 35 to $150 \mathrm{mg} \mathrm{L}^{-1}$, and biosorbent dose in the range $50-300$ $\mathrm{mg} \mathrm{L}^{-1}$, were examined. The effect of these parameters on the cadmium removal was analyzed and optimized using full factorial design methodology and the analysis of variance. The kinetics were modelized for pseudo-second order and pseudo-first order models. Results showed that the pseudo-second order kinetic gave the best fit for equilibrium data. The biosorption isotherms were investigated for Freundlich and Langmuir models. Langmuir isotherm model gave the best fit and led to a maximum biosorption capacity of $\mathrm{Cd}(\mathrm{II})$ on FS of $52.08 \mathrm{mg} \mathrm{g}^{-1}$. The results indicated that FS of was effective in the removal of cadmium ions. Optimum $\mathrm{Cd}(\mathrm{II})$ removal of $88.2 \%$ was calculated for $\mathrm{pH} \mathrm{3,} 75 \mathrm{mg} \mathrm{L}^{-1}$ of $\mathrm{Cd}(\mathrm{II})$ and $250 \mathrm{mg} \mathrm{L}^{-1}$ of FS. Monte Carlo simulation was used as relatively greener pathway to study the biosorption behavior of $\mathrm{Cd}(\mathrm{II})$ ions onto FS. It showed that the interaction Cd(II) - hydroxyapatite was more favored than Cd(II) - collagen.

Key words: Biosorption; Cadmium ions; Fish scale; Full factorial design; Analysis of variance; Monte Carlo method 


\section{Introduction}

Heavy metals constitute a large class of persistent pollutants in the environment. Various techniques have been employed to remove heavy metals from waters or soils, such as phytoremediation [1], adsorption onto low-cost materials [2,3] or solvent extraction [4]. The choice of the treatment depends upon the nature of the matrix and the concentration of the targeted metals. Among these treatments, adsorption onto various materials is the main process which allows efficient and easy removal of heavy metals [5-7]. Among these metals, cadmium is known as one of the most harmful toxicants [8-10] and a lot of techniques have been investigated for its removal from water, such as precipitation, membrane filtration and adsorption [11], electrocoagulation [12-15] or membrane separation [16,17]. Physical processes require complex equipment and this fact explains the success of adsorptive removal of cadmium by low-cost adsorbents $[18,19]$ and nanoadsorbents $[20,21]$. These adsorbents are particularly interesting in the context of the present work because, like fish scales, they contain nano-hydroxyapatite. Indeed, several studies have shown that nano crystallites of hydroxyapatite (HAP) and collagen fibers are the main constituents of fish scales [22,23].

Many waste materials, including by-products arising from fish processing industries [24], have been used as biosorbent. Particularly, fish scales (FS) have been investigated as biosorbents of pollutants [23,25,26] and heavy metals [22,27-30]. The adsorption of cadmium ions has been rarely investigated [31]. For the first time, in the present work, the use of FS of Sardina pilchardus was studied as biosorbent of $\mathrm{Cd}(\mathrm{II})$ ions in synthetic waste waters. The process parameters such as effect of initial $\mathrm{pH}$, biosorbent dose and initial cadmium ions concentration were studied. Langmuir and Freundlich isotherm models were applied. The kinetics was also analyzed for pseudo-first order and pseudo-second order models. Thermodynamic parameters were calculated to complete the investigation of Cd(II) removal. Design Of Experiments (DOE) has been used as a method to establish the relationship between different factors influencing a process and its output [32]. The DOE method can be divided in full factorial design (FFD), where all combinations of the parameter levels are evaluated in order to analyze the results. Full factorial design was used to optimize and analyze the effect of these parameters. Several researchers used full factorial DOE methods in their works [32]. In addition, Monte Carlo simulation was applied to evaluate the biosorption behavior of cadmium ions onto the two main constituents of FS, the nanoparticles of hydroxyapatite and the fibers of collagen. 


\section{Materials and methods}

\subsection{Reagents}

Cadmium nitrate $\left(\mathrm{Cd}\left(\mathrm{NO}_{3}\right)_{2}, 4 \mathrm{H}_{2} \mathrm{O}\right)$ was purchased from Sigma Aldrich. The other chemicals, sodium hydroxide $(\mathrm{NaOH})$ and sulfuric acid $\left(\mathrm{H}_{2} \mathrm{SO}_{4}\right)$ were purchased from Scharlau Chemie.

\subsection{Preparation of FS}

FS of Sardina pilchardus were collected from a local restaurant in June 2019, in the city of Safi, Morocco. They were rinsed with distilled water two times and then dried at $353 \mathrm{~K}$ for $24 \mathrm{~h}$. Finally, the dried FS was cut into small pieces using domestic mixer. The biosorbent FS was stored in a glass bottle for further use without further treatment.

\subsection{Adsorption studies}

Biosorption experiments were conducted by adding $250 \mathrm{mg}$ of FS to a set of 100 $\mathrm{mL}$ conical flasks containing $50 \mathrm{~mL}$ of cadmium solutions with initial concentrations of 75 $\mathrm{mg} \mathrm{L}^{-1}$ at $\mathrm{pH} 3$. The flasks were shaken at a constant agitation speed, and at room temperature for $1 \mathrm{~h}$. The effect of the biosorbent mass was carried out by varying the FS mass from $50 \mathrm{mg}$ to $300 \mathrm{mg}$.

For all other experiments, $250 \mathrm{mg}$ of biosorbent were used. These experiments were carried out by changing the initial cadmium concentration from $35 \mathrm{mg} \mathrm{L}^{-1}$ to $150 \mathrm{mg} \mathrm{L}^{-1}$, the $\mathrm{pH}$ from 2.14 to 7.76 . The initial $\mathrm{pH}$ was adjusted by adding $0.1 \mathrm{M} \mathrm{NaOH}$ or $0.1 \mathrm{M}$ $\mathrm{HCl}$. Each experiment was replicated three times.

After each biosorption experiment the samples were centrifuged at $4000 \mathrm{rpm}$ for 4 min to separate the liquid phase from the solid phase. The concentration of the $\mathrm{Cd}(\mathrm{II})$ ions in the solution was determined using an atomic absorption spectrometer (SavantAA-GBC) at maximum wavelength, $\lambda_{\max }=326.2 \mathrm{~nm}$. The percentage removal of cadmium ions was given by Eq. (1) where $\left[C d^{2+}\right]_{i}$ is the initial concentration of cadmium ions, and $\left[\mathrm{Cd}^{2+}\right]_{t}$ is the concentration of cadmium ions at reaction time $t$.

Percentage removal $(\%)=\left(\frac{\left[\mathrm{Cd}^{2+}\right]_{i}-\left[C d^{2+}\right]_{t}}{\left[C d^{2+}\right]_{i}}\right) \times 100$

The biosorbed amount at time $t, q_{t}\left(\mathrm{mg} \mathrm{g}^{-1}\right)$, was computed from the concentration of the $\mathrm{Cd}(\mathrm{II})$ solution according to Eq. (2) where $C_{i}\left(\mathrm{mg} \mathrm{L}^{-1}\right)$, and $C_{t}\left(\mathrm{mg} \mathrm{L}^{-1}\right)$ are initial 
concentration and concentration at time $t$ of $\mathrm{Cd}(\mathrm{II})$ ions, respectively, $V$ is the volume of the cadmium solution (L), and $m$ is the mass of FS (g).

$q_{t}=\left(C_{i}-C_{t}\right) \frac{V}{m}$

\subsection{Kinetic study}

Kinetic study represents an important experiment to understand the adsorption process. The pseudo-first order and the pseudo-second order models have been used in this study. The pseudo-first order equation is expressed by Eq. (3) [33] where $k_{1}\left(\mathrm{~min}^{-1}\right)$ is the rate constant of pseudo-first order sorption, $t$ is time, $q_{e}\left(\mathrm{mg} \mathrm{g}^{-1}\right)$ and $q_{t}\left(\mathrm{mg} \mathrm{g}^{-1}\right)$ are the sorption capacities at equilibrium and at time $t$, respectively.

$\ln \left(q_{e}-q_{t}\right)=\ln \left(q_{e}\right)-k_{1} t$

The pseudo-second order kinetic equation is expressed by Eq. (4) [34] where $k_{2}$ is the rate constant of the pseudo-second order sorption $\left(\mathrm{g} \mathrm{mg}^{-1} \mathrm{~min}^{-1}\right), t$ is time, and $q_{e}\left(\mathrm{mg} \mathrm{g}^{-}\right.$ $\left.{ }^{1}\right)$ and $q_{t}\left(\mathrm{mg} \mathrm{g}^{-1}\right)$ are the sorption capacity at equilibrium and at time $t$, respectively.

$$
\frac{t}{q_{t}}=\frac{1}{k_{2} q_{e}^{2}}+\frac{1}{q_{e}} t
$$

\subsection{Biosorption isotherm models}

The sorption isotherms obtained were tested with the Langmuir and Freundlich isotherm equations. The Langmuir isotherm model assume that the adsorption of molecules occurs at specific homogeneous sites of the adsorbent and, once a molecule occupies a site, no additional adsorption can occur there (monolayer coverage) [35]. The Freundlich isotherm model assumes the molecules undergoes adsorption onto the heterogeneous surface of adsorbent. This model describes a multilayer adsorption with interaction between adsorbed molecules [35].

Langmuir isotherm can be represented by Eq. (5) [36] where $q_{e}$ and $C_{e}$ are adsorbed amount $\left(\mathrm{mg} \mathrm{g}^{-1}\right)$, and adsorbate concentration in solution $\left(\mathrm{mg} \mathrm{L}^{-1}\right)$ at equilibrium, respectively.

$\frac{C_{e}}{q_{e}}=\frac{1}{q_{m}} C_{e}+\frac{1}{q_{m} K_{L}}$

The plot of $1 / q_{e}$ versus $1 / C_{e}$ should give a straight line. The slope has the value of $1 / K_{L} q_{m}$, where $K_{L}\left(\mathrm{~L} \mathrm{mg}^{-1}\right)$ is the Langmuir constant and $q_{m}\left(\mathrm{mg} \mathrm{g}^{-1}\right)$ is the maximum biosorption capacity. From the highest initial dye concentration $C_{o}\left(\mathrm{mg} \mathrm{L}^{-1}\right)$ and the Langmuir constant $K_{L}\left(\mathrm{~L} \mathrm{mg}^{-1}\right)$, the dimensionless equilibrium parameter $R_{L}$ can be expressed by Eq. (6) [37]:

$R_{L}=\frac{1}{1+K_{L} C_{0}}$ 
The nature of the biosorption process is characterized by the $R_{L}$ value, e.g. unfavorable $\left(R_{L}>1\right)$; linear $\left(R_{L}=1\right)$; favorable $\left(0<R_{L}<1\right)$; irreversible $\left(R_{L}=0\right)$ [38]. Freundlich model [39] considers mono-layer biosorption of solute by the biosorbent and assumes that the biosorbent has an energetically heterogeneous surface or surface supporting sites of varied affinities and the existence of an interaction between the molecules that are adsorbed onto that heterogeneous surface [39]. The Freundlich equation suggests that the biosorption energy exponentially decreases on completion of the active centers of a biosorbent. The Freundlich biosorption isotherm is given by Eq. (7) [40] where $q_{e},\left(\mathrm{mg} \mathrm{g}^{-1}\right)$ is the adsorbed amount and $C_{e}\left(\mathrm{mg} \mathrm{L}^{-1}\right)$ is the adsorbate concentration at equilibrium.

$q_{e}=K_{F} C_{e}^{\frac{1}{n}}$

Biosorption capacity $\left(K_{F}\right)$ and intensity of biosorption $(n)$ are Freundlich constants, which affect the biosorption process. The constants $K_{F}$ and $n$ are calculated from the previous equation by plotting $\ln \left(C_{e}\right)$ versus $\ln \left(q_{e}\right)$ (intercept $=\ln \left(K_{F}\right)$ and slope $=1 / n$ ). In addition, the $n$ value is a measure of the nature and strength of the biosorption process and of the distribution of active sites. The intensity of biosorption less than one $(n<1)$ demonstrates that the biosorption process is of chemical nature. Whereas, the intensity of biosorption more than one $(n>1)$ indicates favorable biosorption conditions [41].

\subsection{Full factorial design}

Statistical analysis was performed using JMP software [42-44]. Data was analyzed by the analysis of variance (ANOVA). A full factorial design of 24 experiments (three factors at two levels) with duplicates was carried out to investigate the influence of the three factors including their interactions on the biosorption of cadmium ions onto FS biosorbent. The three factors were the $\mathrm{pH}$ (2.5 and 5.6), the dose of $C d^{2+}$ (60 and $100 \mathrm{mg}$ $\mathrm{L}^{-1}$ ) and mass of the biosorbent (200 and $300 \mathrm{mg}$ ), as shown in Table 1. The response to be analyzed is the Cadmium ions removal (\%).

\section{Table 1}

Parameters, experimental range and level of independent variables.

\begin{tabular}{lccc}
\hline & & \multicolumn{2}{c}{ Coded variables $\mathrm{X}_{1}, \mathrm{X}_{2}, \mathrm{X}_{3}$} \\
\hline Natural variables $\left(\mathrm{x}_{\mathrm{j}}\right)$ & Units & -1 & 1 \\
\hline $\mathrm{X}_{1}=\mathrm{pH}$ & - & 2.5 & 5.6 \\
$\mathrm{x}_{2}=\left[\mathrm{Cd}^{2+}\right]$ & $\mathrm{mg} / \mathrm{L}$ & 60 & 100
\end{tabular}




\subsection{MC simulation}

The MC simulation [44] was performed using a different Miller plans of HAP ((211), (112), (300) (002), (310), (213) and (411) with cell dimensions of $a=b=9.342 \AA$, containing a vacuum layer of $20 \AA$ along the $C$-axis; and then their optimizations were completed utilizing Materials studio software version 8.0 [45] using DMol3 module at the $\mathrm{DNP}+$ basis set and B3LYP functional. Concerning the original structure of type I collagen was extracted from the Protein Data Bank under its PDB form [46], and then the entire structure of Collagen was subjected to achieve its corresponding biosorption simulation

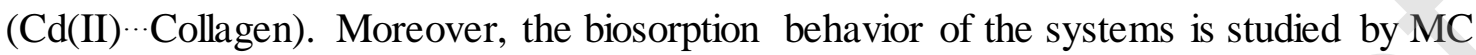
simulation in two environments, in vacuum (60Cd(II)/HAP or collagen) and in acidic solution $\left(60 \mathrm{Cd}(\mathrm{II}), 200 \mathrm{H}_{2} \mathrm{O}, 20 \mathrm{H}_{3} \mathrm{O}^{+}, 5 \mathrm{SO}_{4}{ }^{2-} / \mathrm{HAP}\right.$ or Collagen) using COMPASS II force field [47] by means the biosorption locator module [44] integrating in Biovia Materials studio version 8.0.

\section{Results and discussion}

\subsection{Effect of initial $\mathrm{pH}$ for the removal efficiency of cadmium ions}

The $\mathrm{pH}$ effect on biosorption behavior of cadmium ions onto FS was investigated in the $\mathrm{pH}$ range 2.14-7.76, because in alkaline solutions the precipitation of $\mathrm{Cd}(\mathrm{OH})_{2}$ occurs $[11,48]$. The results are presented in Fig. 1. The maximum uptake can be observed at initial $\mathrm{pH}$ 3.00. In a strong acidic medium, $\mathrm{Cd}$ (II) ions slowly adsorbed on the surface which is already saturated by $\mathrm{H}^{+}$ions. Because these protons compete with the $\mathrm{Cd}(\mathrm{II})$ ions. This effect is absorbed by increasing the $\mathrm{pH}$, because there is a decrease in the competition between the $\mathrm{H}^{+}$ions in solution and the metal cations at the surface biosorption sites. However, in the strong basic medium $\mathrm{Cd}(\mathrm{II})$ ions react with $\mathrm{HO}^{-}$ions and lead to cadmium hydroxide $\mathrm{Cd}(\mathrm{OH})_{2}$. Consequently, the initial $\mathrm{pH}$ is fixed at 3 for the other studies. 


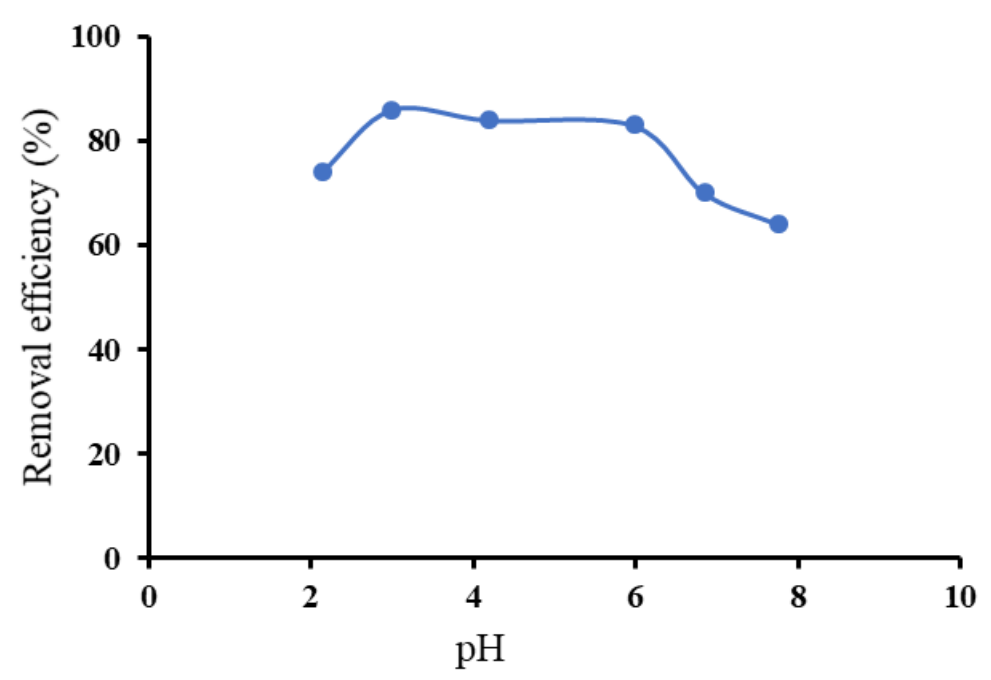

Fig. 1. Effect of $\mathrm{pH}$ on the cadmium biosorption onto $\mathrm{FS}\left(\left[\mathrm{Cd}^{2+}\right]_{\mathrm{i}}=75 \mathrm{mg} \mathrm{L}^{-1}, \mathrm{~m}_{(\mathrm{FS})}=250\right.$ mg, $\mathrm{t}=1 \mathrm{~h}, \mathrm{~V}=50 \mathrm{~mL}, \mathrm{pH}=3, \mathrm{~T}=298 \mathrm{~K})$.

\subsection{Effect of adsorbate concentration}

The influence of initial cadmium concentration on its biosorption was also investigated at room temperature using constant biosorbent dose. Fig. 2 shows the influence of the cadmium concentration on its biosorption. Five concentrations of cadmium ions were considered $\left(35,50,75,100\right.$ and $\left.150 \mathrm{mg} \mathrm{L}^{-1}\right)$. Fig. 2 reveals that biosorption efficiency is higher at lower initial cadmium concentration (35 mg L-1) and a slow decrease in $\mathrm{Cd}$ (II) biosorption by FS was observed with increasing initial $\mathrm{Cd}(\mathrm{II})$ concentration. The reason for the decrease in cadmium removal efficiency at higher initial concentration may be due to saturation of the active sites of the adsorbent by the cadmium ions and hence.

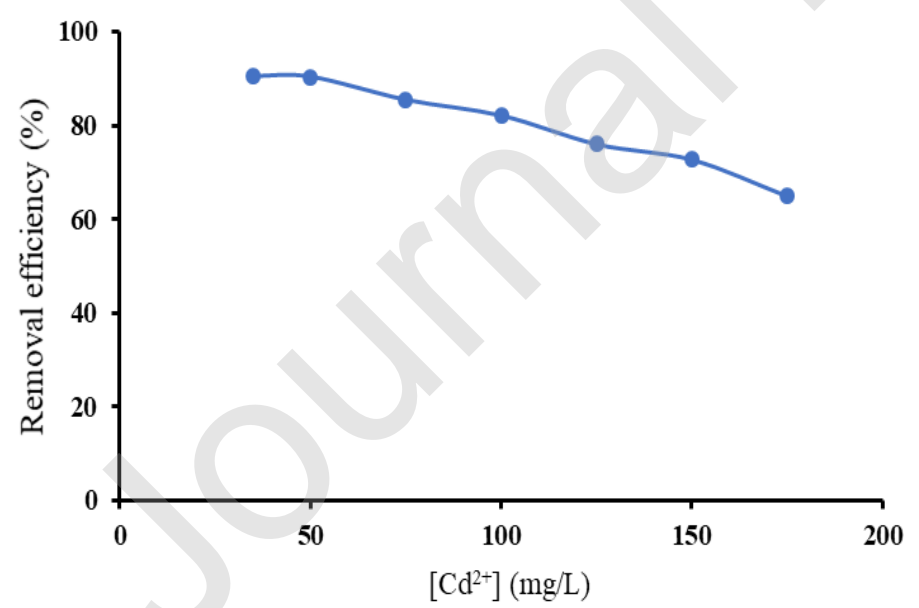

Fig. 2. Effect of cadmium dose on its biosorption $\left(\mathrm{m}_{(\mathrm{FS})}=250 \mathrm{mg}, \mathrm{t}=1 \mathrm{~h}, \mathrm{~V}=50 \mathrm{~mL}, \mathrm{pH}=3\right.$, $\mathrm{T}=298 \mathrm{~K})$.

\subsection{Effect of FS dose}


The effect of biosorbent dose on cadmium removal is shown in Fig. 3. Results show that the biosorption efficiency of FS increases with the increase in biosorbent dose. After $60 \mathrm{~min}$ of stirring the cadmium ions solution and FS, the cadmium removal percentage varied from $20.90 \%$ for $50 \mathrm{mg}$ of FS to $89.44 \%$ for $300 \mathrm{mg}$ of FS. The increase in the removal efficiency of $\mathrm{Cd}(\mathrm{II})$ may be attributed to the fact that with the increase in biosorbent dose, the available surface for biosorption increases for the cadmium ions to be adsorbed [49,50]. The best dose of biosorbent was found to be $250 \mathrm{mg}$ of FS per $50 \mathrm{~mL}$ of cadmium ions solution for the following studies, because this amount gives $88.20 \%$ of cadmium removal, almost same removal percentage of $300 \mathrm{mg}(89.44 \%)$.

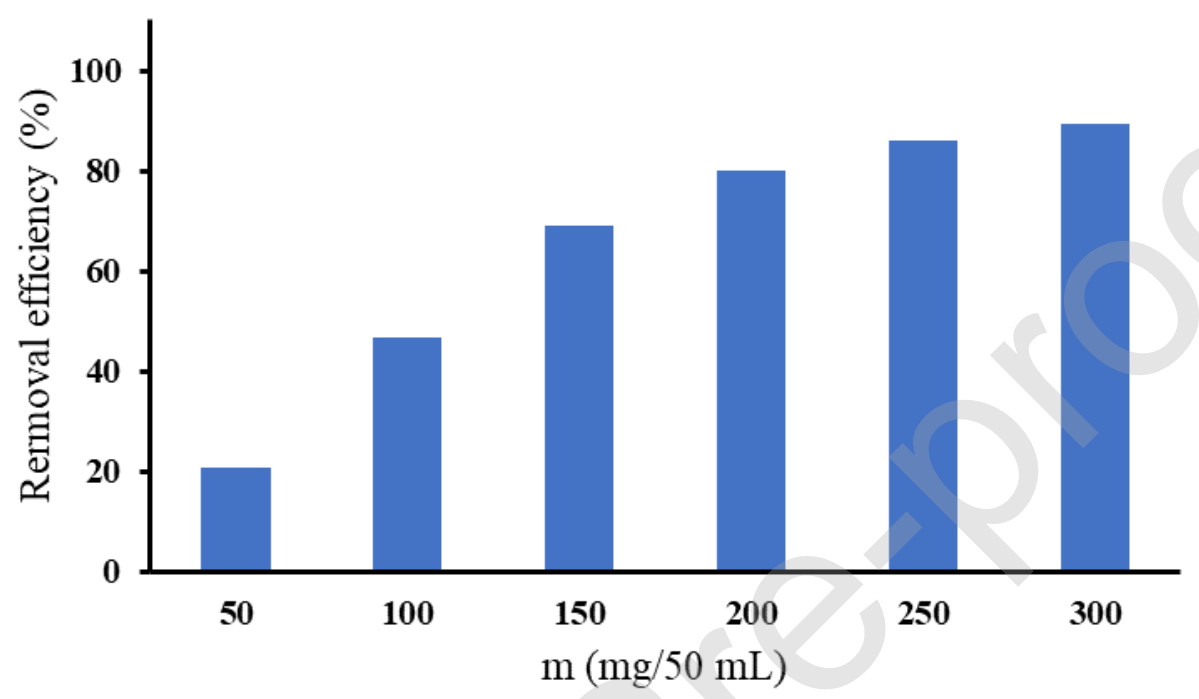

Fig. 3. Effect of FS dose on the biosorption of cadmium $\left(\left[\mathrm{Cd}^{2+}\right]_{i}=75 \mathrm{mg} \mathrm{L}^{-1}, \mathrm{pH} 3, \mathrm{t}=1 \mathrm{~h}\right.$, $\mathrm{V}=50 \mathrm{~mL}, \mathrm{~T}=298 \mathrm{~K})$.

\subsection{Kinetic of biosorption}

The results of Lagergren pseudo-first order kinetic are given in Table 2. A large gap is observed between the experimental $q_{e}(\exp )$ and calculated $q_{e}$ (cal) values. Hence, the biosorption of $\mathrm{Cd}(\mathrm{II})$ onto FS does not obey the pseudo-first order kinetic model. The results of pseudo-second order are gathered in Table 2. The experimental $q_{e}(\exp )$ and calculated $q_{e}(\mathrm{cal})$ values are very close $\left(12.94\right.$ for $\left.12.72 \mathrm{mg} \mathrm{g}^{-1}\right)$. The results indicate that the pseudo-second order model fitted very well to the experimental data, showing high correlation coefficient $R^{2}$ value. Similar results have been reported for the adsorption of $\mathrm{Cd}(\mathrm{II})$ by $\mathrm{Mg}-\mathrm{Al}-\mathrm{CO}_{3}$-layered double hydroxide [51].

\section{Table 2}

Kinetic parameters of the biosorption of the cadmium onto FS.

\begin{tabular}{lll}
\hline Kinetic models & Parameters & Value \\
\hline
\end{tabular}




\begin{tabular}{lll}
\hline & $k_{l}\left(\mathrm{~min}^{-1}\right)$ & 0.067 \\
Pseudo-first order & $q_{\text {exp }}\left(\mathrm{mg} \mathrm{g}^{-1}\right)$ & 12.94 \\
& $q_{\text {cal }}\left(\mathrm{mg} \mathrm{g}^{-1}\right)$ & 10.63 \\
& $R^{2}$ & 0.9874 \\
\hline \multirow{3}{*}{ Pseudo-second order } & $k_{2}\left(\mathrm{~g} \mathrm{mg}^{-1} \mathrm{~min}^{-1}\right)$ & 0.008 \\
& $q_{\text {cal }}\left(\mathrm{mg} \mathrm{g}^{-1}\right)$ & 12.72 \\
& $R^{2}$ & 0.9999 \\
\hline
\end{tabular}

\subsection{Biosorption isotherms}

The results of the experimental data by both isotherm models (Langmuir and Freundlich) are gathered in Table 3 . The value of the correlation coefficient $\left(R^{2}\right)$ of the biosorbent estimated from the Freundlich model was lower than that the one of the Langmuir model (0.93 instead of 0.96), indicating that the Langmuir equation provides a better fit for the experimental data than the Freundlich model.

Therefore, the Langmuir model represents a better biosorption process which saturated monolayer biosorption of adsorbate molecules on the biosorbent surface, and the energy of biosorption is constant, there is no transmigration of adsorbate molecules, in agreement with the assumption of the Langmuir model. Besides, the Langmuir constant $R_{L}$ value $\left(R_{L}=0.22\right)$ for the biosorption of cadmium indicated the favorability of the biosorption.

\section{Table 3}

Isotherm parameters for biosorption of cadmium ions onto FS.

\begin{tabular}{lll}
\hline Isotherm models & Parameters & Values \\
\hline \multirow{3}{*}{ Langmuir } & $K_{L}\left(\mathrm{~L} \mathrm{mg}^{-1}\right)$ & 0.023 \\
& $q_{m}\left(\mathrm{mg} \mathrm{g}^{-1}\right)$ & 52.08 \\
& $R^{2}$ & 0.96 \\
& $R_{L}$ & 0.22 \\
\hline \multirow{2}{*}{ Freundlich } & $K_{F}\left(\mathrm{mg} \mathrm{g}^{-1}\right)$ & 2.04 \\
& $n$ & 1.48 \\
& $R^{2}$ & 0.93 \\
\hline
\end{tabular}

\subsection{Comparison of biosorbents}

A comparative evaluation of the adsorption capacities of other adsorbents for the adsorption of cadmium ions is given in Table 4. It is obvious that FS shows a good biosorption efficiency when it is compared to activated carbon or sodium montmorillonite 
with $3.65 \mathrm{mg} \mathrm{g}^{-1}$ or $16.66 \mathrm{mg} \mathrm{g}^{-1}$, respectively. Regarding the removal of $\mathrm{Cd}(\mathrm{II})$, FS is a better adsorbent after Carp (Cyprinus carpio) scales, S. filipendula and $\mathrm{NaOH}$ treated Aloe vera wastes.

\section{Table 4}

Maximum biosorption capacity of cadmium ions by other adsorbents.

\begin{tabular}{|c|c|c|}
\hline Bios orbent & $q_{m}\left(m g g^{-1}\right)$ & Experime ntal conditions \\
\hline S. filipendula & 103.5 & $\begin{array}{l}{\left[\mathrm{Cd}^{2+}\right]=50.8 \mathrm{mg} \mathrm{L}^{-1}, \mathrm{t}=1 \mathrm{~h},} \\
\mathrm{pH}=5.7, \mathrm{~m}=0.99 \mathrm{~g}, \mathrm{~T}=308 \mathrm{~K} \\
\mathrm{~V}=1 \mathrm{~L}\end{array}$ \\
\hline $\begin{array}{l}\text { Carp (Cyprinus carpio) } \\
\text { scales }\end{array}$ & 68.6 & $\begin{array}{l}{\left[\mathrm{Cd}^{2+}\right]=5 \mathrm{mg} \mathrm{L}^{-1}, 2 \mathrm{~h}, \mathrm{pH}=6,} \\
\mathrm{~m}=10 \mathrm{mg}, \mathrm{T}=298 \mathrm{~K} \\
\mathrm{~V}=100 \mathrm{~mL}\end{array}$ \\
\hline Sodium Montmorillonite & 16.66 & $\begin{array}{l}{\left[\mathrm{Cd}^{2+}\right]=20 \mathrm{mg} \mathrm{L}^{-1}, 1 \mathrm{~h}, \mathrm{pH}=4,} \\
\mathrm{~m}=0.5 \mathrm{~g}, \mathrm{~T}=295 \mathrm{~K} \\
\mathrm{~V}=100 \mathrm{~mL}\end{array}$ \\
\hline Activated carbon & 3.65 & $\begin{array}{l}{\left[\mathrm{Cd}^{2+}\right]=20 \mathrm{mg} \mathrm{L}^{-1}, 1 \mathrm{~h}, \mathrm{pH}=4,} \\
\mathrm{~m}=1 \mathrm{~g}, \mathrm{~T}=295 \mathrm{~K} \\
\mathrm{~V}=100 \mathrm{~mL}\end{array}$ \\
\hline $\begin{array}{l}\mathrm{NaOH} \text { treated Aloe vera } \\
\text { wastes }\end{array}$ & 104.20 & $\begin{array}{l}{\left[\mathrm{Cd}^{2+}\right]=50 \mathrm{mg} \mathrm{L}^{-1}, 6 \mathrm{~h}, \mathrm{pH}=5,} \\
\mathrm{~m}=15 \mathrm{mg}, \mathrm{T}=298 \mathrm{~K}, \mathrm{~V}=10 \mathrm{~mL}\end{array}$ \\
\hline $\begin{array}{l}\text { Fish scales of Sardina } \\
\text { pilchardus }\end{array}$ & 52.08 & $\begin{array}{l}{\left[\mathrm{Cd}^{2+}\right]=75 \mathrm{mg} \mathrm{L}^{-1}, \mathrm{t}=1 \mathrm{~h},} \\
\mathrm{pH}=3, \mathrm{~m}=250 \mathrm{mg}, \mathrm{T}=298 \mathrm{~K} \\
\mathrm{~V}=50 \mathrm{~mL}\end{array}$ \\
\hline
\end{tabular}

\subsection{Full factorial design}

The 24 experiments proposed by JMP were performed. The $i^{\text {th }}$ line of this matrix defines the experimental conditions of the $\mathrm{i}^{\text {th }}$ experiment. To minimize the error due to the experiments, the design is carried out with randomized order; the results obtained are subsequently grouped in Table 5. The exploitation of results is based on the analysis of variance of the model. The computation of the factor coefficients, their interactions and determining their significance are based on specific statistical tests [32].

\section{Table 5}

The experimental data for response according to central composite design

\begin{tabular}{l|l|l|l|l}
\hline $\mathrm{N}^{\circ}$ Experience & $\mathrm{pH}$ & {$\left[\mathrm{Cd}^{2+}\right]\left(\mathrm{mg} \mathrm{L}^{-1}\right)$} & $\mathrm{m}(\mathrm{FS})(\mathrm{mg})$ & \\
\hline
\end{tabular}




\begin{tabular}{|c|c|c|c|c|c|c|c|c|}
\hline $\begin{array}{l}\text { Actual } \\
\text { order }\end{array}$ & $\begin{array}{l}\text { Random } \\
\text { order }\end{array}$ & $\mathrm{X}_{1}$ & $\mathrm{x}_{1}$ & $\mathrm{X}_{2}$ & $\mathrm{x}_{2}$ & $X_{3}$ & $\mathrm{x}_{3}$ & $\begin{array}{l}\text { Cadmium } \\
\text { ions removal } \\
(\%)\end{array}$ \\
\hline 1 & 3 & -1 & 2.5 & -1 & 60 & -1 & 200 & 75.39 \\
\hline 2 & 15 & -1 & 2.5 & -1 & 60 & -1 & 200 & 75.67 \\
\hline 3 & 21 & -1 & 2.5 & -1 & 60 & -1 & 200 & 76.70 \\
\hline 4 & 10 & 1 & 5.6 & -1 & 60 & -1 & 200 & 85.50 \\
\hline 5 & 18 & 1 & 5.6 & -1 & 60 & -1 & 200 & 85.35 \\
\hline 6 & 24 & 1 & 5.6 & -1 & 60 & -1 & 200 & 85.70 \\
\hline 7 & 14 & -1 & 2.5 & 1 & 100 & -1 & 200 & 73.40 \\
\hline 8 & 17 & -1 & 2.5 & 1 & 100 & -1 & 200 & 73.60 \\
\hline 9 & 20 & -1 & 2.5 & 1 & 100 & -1 & 200 & 73.29 \\
\hline 10 & 1 & 1 & 5.6 & 1 & 100 & -1 & 200 & 60.56 \\
\hline 11 & 11 & 1 & 5.6 & 1 & 100 & -1 & 200 & 63.60 \\
\hline 12 & 12 & 1 & 5.6 & 1 & 100 & -1 & 200 & 59.84 \\
\hline 13 & 13 & -1 & 2.5 & -1 & 60 & 1 & 300 & 95.67 \\
\hline 14 & 16 & -1 & 2.5 & -1 & 60 & 1 & 300 & 97.20 \\
\hline 15 & 23 & -1 & 2.5 & -1 & 60 & 1 & 300 & 96.40 \\
\hline 16 & 4 & 1 & 5.6 & -1 & 60 & 1 & 300 & 89.60 \\
\hline 17 & 19 & 1 & 5.6 & -1 & 60 & 1 & 300 & 88.09 \\
\hline 18 & 8 & 1 & 5.6 & -1 & 60 & 1 & 300 & 88.65 \\
\hline 19 & 2 & -1 & 2.5 & 1 & 100 & 1 & 300 & 78.40 \\
\hline 20 & 5 & -1 & 2.5 & 1 & 100 & 1 & 300 & 79.20 \\
\hline 21 & 6 & -1 & 2.5 & 1 & 100 & 1 & 300 & 80.06 \\
\hline 22 & 7 & 1 & 5.6 & 1 & 100 & 1 & 300 & 69.41 \\
\hline 23 & 9 & 1 & 5.6 & 1 & 100 & 1 & 300 & 68.38 \\
\hline 24 & 22 & 1 & 5.6 & 1 & 100 & 1 & 300 & 66.80 \\
\hline
\end{tabular}

\subsection{Variance analysis}

Variance analysis evaluates if the selected variables of the model have a significant effect on the response [55]. According to analysis of variance (Table 6), the $F_{\text {statistics }}$ value of regression for Cadmium ions removal $(\%)$ is higher than $F_{t h}\left(F_{0.01}(6.17)=6.56\right)$. The large value of $F$ indicates that the variation in the response can be explained by the regression equation. 
The associated $p$-value confirms the interpretation determined by Fisher test. The $p$ value of the model is lower than 0.05 . Consequently, these results mean that there is no statistical difference between the experimental values and the estimated values of the models [56].

\section{Table 6}

Variance analysis (ANOVA)

\begin{tabular}{llllll}
\hline Source & $\begin{array}{l}\text { Degree of } \\
\text { freedom }\end{array}$ & $\begin{array}{l}\text { Sum of } \\
\text { squares }\end{array}$ & $\begin{array}{l}\text { Mean } \\
\text { square }\end{array}$ & $F_{\text {statistics }}$ & Prob. $>F$ \\
\hline Model & 6 & 2529.7332 & 421.622 & 46.6344 & $<.0001^{*}$ \\
Residual & 17 & 153.6971 & 9.041 & & \\
Total & 23 & 2683.4303 & & & \\
\hline
\end{tabular}

$F_{\text {statistics }}$ : Experimental Fisher factor

* significant to $1 \%\left(F_{0.01}(6.17)=6.56\right)$

\subsection{Graphical study of the effect of the factors}

The graphs illustrated in Fig. 4 describe the effect of the three factors on the response. First factor, it should be noted that the $\mathrm{pH}$ reflects a small negative effect on the $\mathrm{Cd}(\mathrm{II})$ ions removal. The second factor, which is the dose of $\mathrm{Cd}^{2+}$, has a negative effect on the response. Because increasing the concentration of $\mathrm{Cd}^{2+}$ significantly decreases the $\mathrm{Cd}(\mathrm{II})$ ions removal. The mass of the biosorbent has a positive effect on the rate. In fact, to increase the $\mathrm{Cd}^{2+}$ removal, the mass of the biosorbent must be increased.

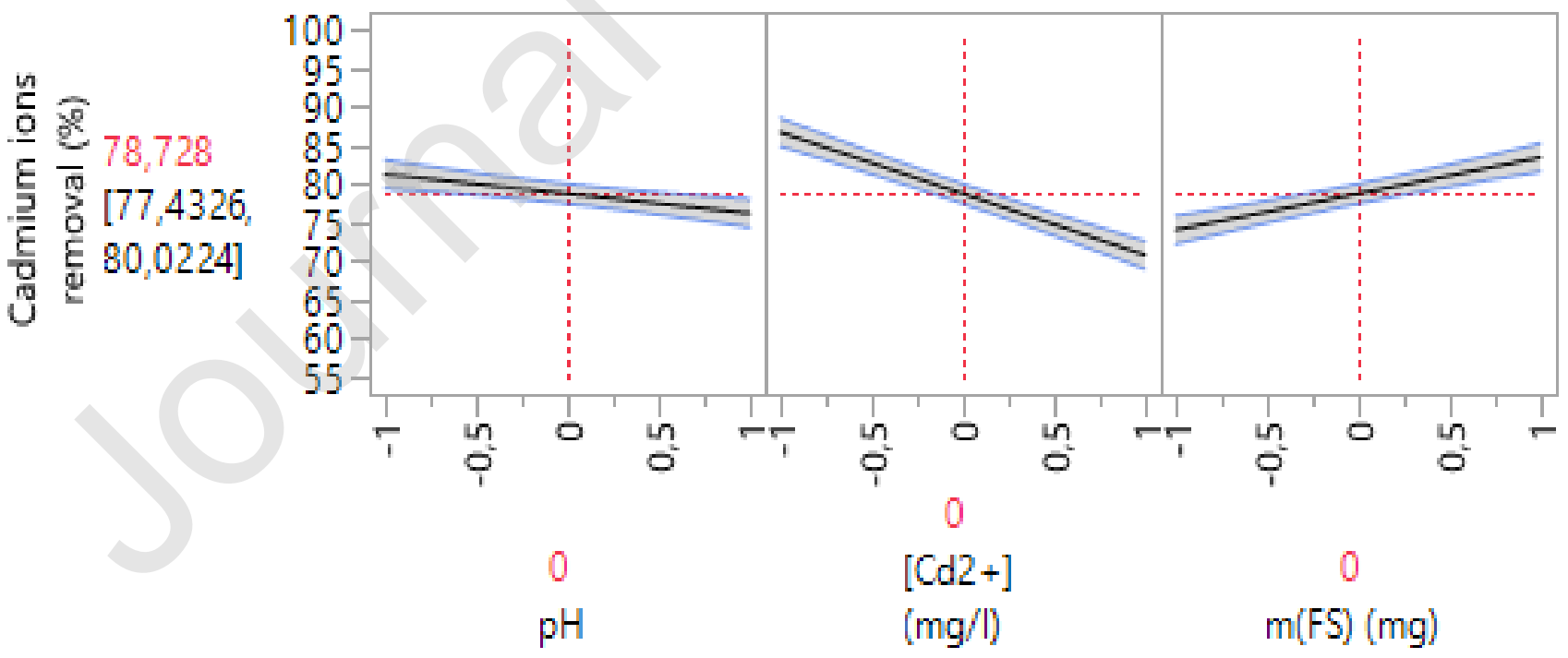

Fig. 4. Main effects plot of parameters on the response.

\subsection{The statistical study of factors effects}


The main effects of the three variables studied and their interactions are presented in Table 7. Each coefficient is associated with the statistical values of $F_{\text {experimental }}$ and a $p$ value.

The Fisher test is used to determine the importance and significance of the effects of the factors and interactions between the variables on the responses studied. Generally, the largest amplitude of $F$ corresponds to the smallest value of $p$ [55].

We note in Table 7 that for a confidence level of $99.9 \%$ the linear effects of the three factors have a significant effect on the removal of Cadmium ions (\%), with a values of $F_{\text {experimental }}\left(16.8687,167.0378,58.0794\right.$ for the $p H$, the $\mathrm{Cd}^{2+}$ dose and the mass of the biosorbent respectively) largely higher than the critical value of Fisher $\left(F_{t h}=5.99\right)$.

Similarly, we note that the two interactions $\mathrm{pH}^{*}\left[\mathrm{Cd}^{2+}\right]$ and $\mathrm{pH} * \mathrm{~m}(\mathrm{FS})$ have a significant effect on the response with very high values of the $F_{\text {experimental }}$ On the other hand, we note that the interaction $\left[\mathrm{Cd}^{2+}\right]^{*} \mathrm{~m}(\mathrm{FS})$ has no significant effect on the removal of $\mathrm{Cd}(\mathrm{II})$ ions $(\%)$.

\section{Table 7}

Result of multiple linear regression of the $\mathrm{Cd}(\mathrm{II})$ ions removal (\%)

\begin{tabular}{|c|c|c|c|c|c|}
\hline Model term & Estimation & $\begin{array}{l}\text { Sum of } \\
\text { squares }\end{array}$ & $F_{\text {experimental }}$ & Prob. > F & Significance \\
\hline Constante & 78.7275 & - & - & $<.0001$ & $* * *$ \\
\hline $\mathrm{pH}$ & -2.520833 & 152.5104 & 16.8687 & 0.0007 & $* * *$ \\
\hline$\left[\mathrm{Cd}^{2+}\right]$ & -7.9325 & 1510.1894 & 167.0378 & $<.0001$ & $* * *$ \\
\hline m(FS) & 4.6775 & 525.0962 & 58.0794 & $<.0001$ & $* * *$ \\
\hline $\mathrm{pH} \mathrm{H}^{*}\left[\mathrm{Cd}^{2+}\right]$ & -3.009167 & 217.3220 & 24.0374 & 0.0001 & $* * *$ \\
\hline $\mathrm{pH} \mathrm{H}^{*} \mathrm{~m}(\mathrm{FS})$ & -1.895833 & 86.2604 & 9.5410 & 0.0067 & $* *$ \\
\hline$\left[\mathrm{Cd}^{2+}\right] * \mathrm{~m}(\mathrm{FS})$ & -1.264167 & 38.3548 & 4.2423 & 0.0551 & NS \\
\hline
\end{tabular}

\subsection{Modelization}

To describe the variation of the responses according to influencing factors, we choose to use a polynomial model that will be descriptive and representative of the model (Eq. (9)):

$$
Y=b_{0}+b_{1} X_{1}+b_{2} X_{2}+b_{3} X_{3}+b_{12} X_{1} X_{2}+b_{13} X_{1} X_{3}+b_{23} X_{2} X_{3}
$$

Where: 
- Y: the value of the calculated response,

- $\mathrm{X}_{\mathrm{i}}$ : the value of the coded variable "i"

- $b_{i}$ : The coefficient of the variable $X_{i}$ model,

- $b_{i j}$ : The coefficient of the interaction model between $X_{i}$ and $X_{j}$.

This model has 7 terms:

- Constant term $=1$

- Linear term $=3$

- Rectangle term $=3$

The mathematical model only considers the factors having $p$-value $<0.05$. This model is written as follows (Eq. (10)):

Cadmium ions removal $(\%)=78.7275-2.520833 \mathbf{p H}-7.9325\left[\mathbf{C d}^{2+}\right]+4.6775 \mathbf{~ m}(\mathbf{F S})-$ $3.009167 \mathbf{p H} *\left[\mathbf{C d}^{2+}\right]-1.895833 \mathbf{p H} * \mathbf{m}(\mathbf{F S})$

\subsection{Validation of the model}

The correlation between the predicted and experimental values is shown in Fig. 5, characterized by point clouds whose alignment is close to a straight line [57]. The condition of normality of the residuals is thus well respected for the model. Indeed, in this model, the value of $\mathrm{R}^{2}$ was evaluated at 0.94 indicating that $94 \%$ of the established model could explain the variability of the response $\mathrm{Cd}(\mathrm{II})$ ions removal (\%).

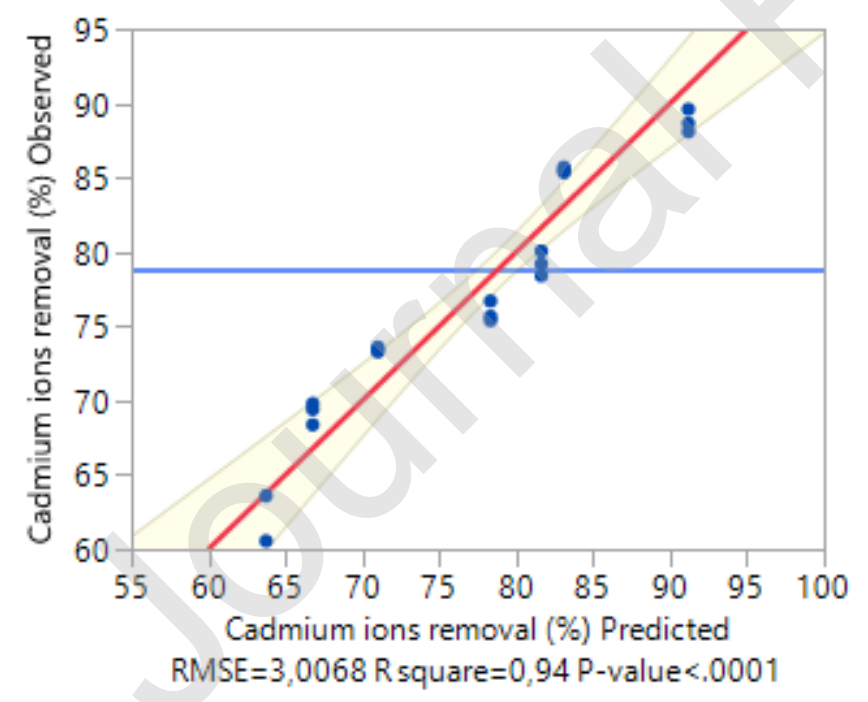

Fig. 5. Correlation between experimental and predicted values for the response (Cadmium ions removal (\%)).

In addition, the model is characterized by very high values of the correlation coefficient and the adjusted coefficient of determination $\left(R_{c}=0.9709\right.$ of $\left.R^{2}{ }_{A}=0.9225\right)$ 
indicates a very good correlation between the estimated values and the experimental results. Likewise, we found that the Durbin-Watson statistic ( $D-W=2.68$ ) is close to 2 indicating a good quality of the fit of the model. Therefore, a low value of the root-meansquare error $(\mathrm{RMSE}=3.0068)$ confirms that the model explains perfectly the studied process.

The experimental values, the predicted values and their deviations are grouped in Table 7. After the analysis we see that there is no statistically significant difference between these values.

\subsection{Optimization}

The response surfaces as well as the iso-response curves (Fig. 6) were used to determine the best conditions for removing cadmium ions. The factors studied $\left(\mathrm{pH}\left(\mathrm{x}_{1}\right)\right.$ and the mass of FS $\left(\mathrm{x}_{3}\right)$ at a fixed value initial concentration of $\mathrm{Cd}^{2+}$ ions $\left.\left(\mathrm{x}_{2}\right)\right)$ were evaluated to obtain the highest percentage removal of $\mathrm{Cd}^{2+}$ ions at the end of the process, with the convergence of the target (desirable) towards the maximum value.
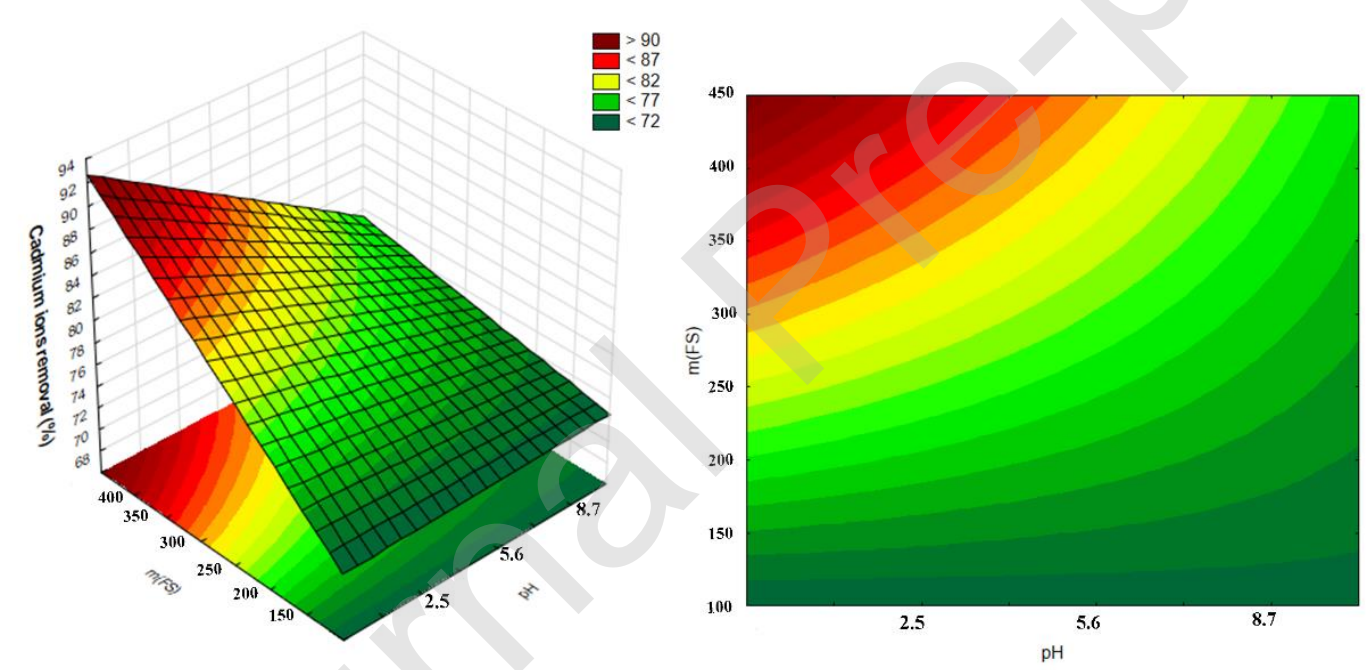

Fig. 6. Response surfaces (in left) and iso-response curves (in right) of percentage removal of Cadmium ions as a function of $\mathrm{pH}\left(\mathrm{x}_{1}\right)$ and the mass of $\mathrm{FS}$ at a fixed value of the concentration of $\mathrm{Cd}^{2+}$ ions

Fig. 6 shows clearly that the most effective factor to the response (percentage of removal of $\mathrm{Cd}^{2+}$ ions) was the mass of FS. It is possible to verify that the linear term of the mass of FS as well as the interaction with the $\mathrm{pH}$ contributes positively to the response, since when this factor increases the response increases consequently. The optimum conditions of biosorption were determined to be $\mathrm{pH}\left(\mathrm{x}_{1}\right)$ at 3 , concentration of Cadmium 
ions $\left(\mathrm{x}_{2}\right)$ at $75 \mathrm{mg} \mathrm{L}^{-1}$ and mass of $\mathrm{FS}\left(\mathrm{x}_{3}\right)$ at $250 \mathrm{mg}$. Thus, it was not necessary to carry out other experiments different from those proposed by the experimental design because the best working condition was that of the experimental points.

The best average experimental result was $88.20 \%$ for the percentage removal of cadmium ions, and the value predicted by the model was $85 \%$. The difference between the experimental value and the predicted value was $3.20 \%$.

\subsection{Biosorption behavior using MC simulations}

The MC simulation can predict the biosorption behavior of $\mathrm{Cd}(\mathrm{II})$ ions onto major constituents of FS (HAP and collagen) separately, because this biosorption obeys a Langmuir isotherm model (monolayer biosorption and the energy of biosorption is constant). Fig. 7 exposes the top views of the equilibrium biosorption of the studied Miller plans of HAP in vacuum and in solution. Then, Fig. 8 shows the top views of the equilibrium biosorption of collagen in both vacuum and solution. Some parameters related to the biosorption of $\mathrm{Cd}(\mathrm{II})$ ions onto $\mathrm{FS}$ are calculated, such as the total energy $\left(E_{T}\right)$ reports the global energy for the system, this parameter is calculated by optimizing the whole system; the biosorption energy $\left(E_{a d s}\right)$ which displays the energy required when the relaxed $\mathrm{Cd}(\mathrm{II})$ ions are biosorbed with the substrate, this parameter is commonly recognized to evaluate the strength and mechanism of biosorption; other term of energy namely the desorption energy $d E_{a d s} / d N i$ reflects the necessary energy which one entity of $\mathrm{Cd}(\mathrm{II})$ is removed to the system of $60 \mathrm{Cd}(\mathrm{II}) /$ vacuum or solution/substrate [58].

Therefore, biosorption behavior (i.e., chemisorption, physisorption) related to the studied systems was evaluated from pair correlation function $\mathrm{g}(\mathrm{r})$ analysis using Forcite calculation code [59] which attained after performing the MC simulation for these systems. This method was suggested as a powerful tool to estimate the lengths bonds into biosorption process. The appearance of peaks with lengths lower than $3.5 \AA$ is considered an indication of small bonds, and is correlated with chemisorption, while physical biosorption behavior is associated with peaks greater than $3.5 \AA$ [60].

From Table 8, we observed that all studied Miller plans have characterized with high negative values of $E_{T}$ and $E_{a d s}$ energies in solution comparing to those in the vacuum; indicating clearly the prominent role of acidic medium to reaching high interaction and stability for biosorption interfaces. In other words, we noticed that $E_{T}$ and $E_{a d s}$ energies related to the $C d(I I)$ ions biosorption on HAP Miller plans in acidic solution increased in the order, HAP $(002)<\operatorname{HAP}(411)<\operatorname{HAP}(300)<\operatorname{HAP}(213)<\operatorname{HAP}(310)<\operatorname{HAP}(211)$ 
$<$ HAP (112). This result shows that the most stable and stronger biosorption related to the HAP (002) Miller plan of HAP.

Additionally, biosorption energy of Cd(II) ions with HAP (002) in acidic solution was estimated as $-901.449 \mathrm{kcal}^{\mathrm{mol}}{ }^{-1}$; while for $\mathrm{Cd}(\mathrm{II})$ ions with Collagen is -233.996 kcal.mol ${ }^{-1}$, suggesting that $\mathrm{Cd}(\mathrm{II}) \cdots \mathrm{HAP}(002)$ interaction is more favored (high negative value of $E_{a d s}$ ) than $\mathrm{Cd}(\mathrm{II}) \cdots$ Collagen, this is due probably to the enormous number of reactive centers and pores that characterize the hydroxyapatite compared to the collagen. This observation is confirmed by the comparison of the desorption energy values, which show the Cd(II) $\cdots$ HAP (002) system has the higher value of $d E_{a d s} / d N i\left(-7.58 .10^{-3} \mathrm{kcal} . \mathrm{mol}^{-}\right.$ 1) comparing to $\mathrm{Cd}(\mathrm{II}) \cdots$ Collagen $\left(-0.913 \mathrm{kcal}^{\mathrm{mol}}{ }^{-1}\right)$. Furthermore, the calculated biosorption energies are negatives, revealing clearly that the studied biosorption is spontaneous. Consequently, the $\mathrm{Cd}(\mathrm{II})$ ions have qualitatively a biosorption capability to interact with the substrate [58].

As demonstrated in Fig. 7, we observed that the $\mathrm{Cd}(\mathrm{II})$ ion has more accessibility to incorporate pores surface of HAP, this is due probably to the $\mathrm{Cd}(\mathrm{II})$ ion has a low value of ionic volume $\left(3.823 .10^{-3} \mathrm{~nm}^{3}\right)$ with respect to those of the interior pores of HAP [61]. This gives to $\mathrm{Cd}(\mathrm{II})$ ions more possibilities to be incorporated inside HAP structure. Fig. 8 reveals that the interactions of $\mathrm{Cd}(\mathrm{II})$ ions with collagen were more probable generated from reactive functional groups which contain nitrogen, oxygen and carbon atoms. As discussed above, the $\mathrm{Cd}(\mathrm{II})$ ions are more biosorbed on the HAP than Collagen; this difference, probably caused by the steric hindrance effects which generated from heteroatoms functional groups over collagen. This provides certainly a weak interaction between the $\mathrm{Cd}(\mathrm{II})$ ions and collagen. Fig. 9 shows that the biosorption type of $\mathrm{Cd}(\mathrm{II})$ ions towards HAP (002) and Collagen substrates is chemisorption behavior (peaks with lengths less than $3.5 \AA$ ); indicates clearly high ability of $\mathrm{Cd}(\mathrm{II})$ ions to coordinate with HAP and Collagen substrates. 


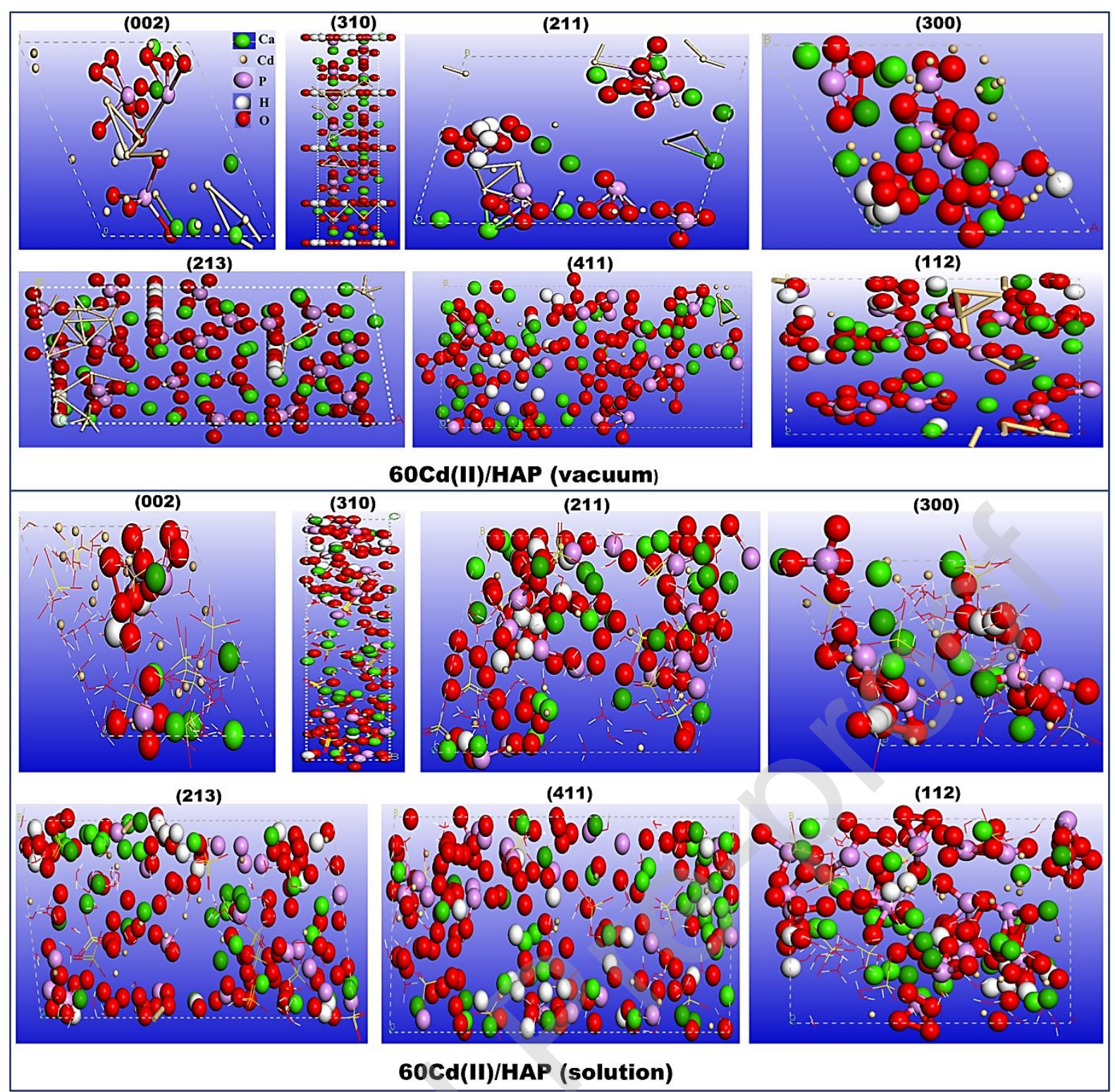

Fig. 7. Top views of stable adsorption configurations of $\mathrm{Cd}(\mathrm{II})$ ions on the HAP surfaces in vacuum $(60 \mathrm{Cd}(\mathrm{II}) / \mathrm{HAP}$ surface $)$ and in acidic solution $\left(60 \mathrm{Cd}(\mathrm{II}), 200 \mathrm{H}_{2} \mathrm{O}, 20 \mathrm{H}_{3} \mathrm{O}+\right.$, $5 \mathrm{SO}_{4}{ }^{2-} / \mathrm{HAP}$ surface) at $298.15 \mathrm{~K}$. 


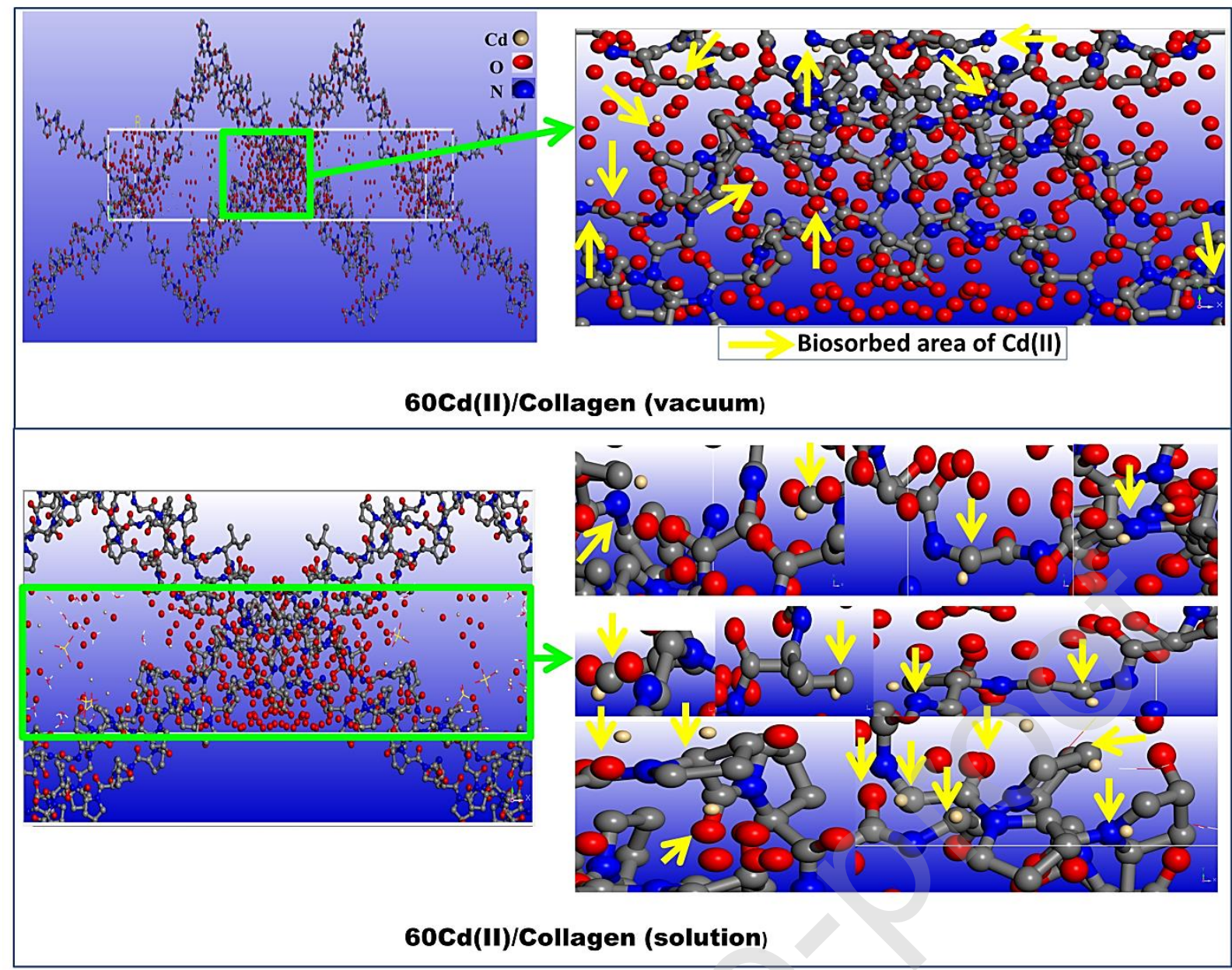

Fig. 8. Top views of stable adsorption configurations of $\mathrm{Cd}(\mathrm{II})$ ions on the collagen in vacuum $(60 \mathrm{Cd}(\mathrm{II}) /$ collagen $)$ and in acidic solution $\left(60 \mathrm{Cd}(\mathrm{II}), 200 \mathrm{H}_{2} \mathrm{O}, 20 \mathrm{H}_{3} \mathrm{O}+, 5 \mathrm{SO}_{4}{ }^{2-}\right.$ /collagen) at $298.15 \mathrm{~K}$.

\section{Table 8}

Total energy $\mathrm{E}_{\mathrm{T}}$, biosorption energy $\mathrm{E}_{\mathrm{ads}}$, and necessary energy to exclude one $\mathrm{Cd}^{2+}$ ions from the surface $\mathrm{dE}_{\mathrm{ads}} / \mathrm{dNi}$ are given in vacuum $(60 \mathrm{Cd}(\mathrm{II}) / \mathrm{HAP}$ or Collagen) and in acidic solution $\left(60 \mathrm{Cd}(\mathrm{II}), 200 \mathrm{H}_{2} \mathrm{O}, 20 \mathrm{H}_{3} \mathrm{O}+, 5 \mathrm{SO}_{4}{ }^{2-/} / \mathrm{HAP}\right.$ or Collagen) at $298.15 \mathrm{~K}$.

\begin{tabular}{|c|c|c|c|c|}
\hline Substrate & & $\left(\right.$ kcal.mol $\left.^{-1}\right)$ & 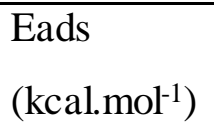 & $\begin{array}{l}\mathrm{dEads} / \mathrm{dNi} \\
\qquad\left(\mathrm{kcal} \mathrm{mol}^{-1}\right)\end{array}$ \\
\hline \multirow[t]{2}{*}{ HAP (002) } & Vacuum & -7.945 & -7.945 & -0.001 \\
\hline & Solution & -878.847 & -901.449 & $-7.58 .10^{-3}$ \\
\hline \multirow[t]{2}{*}{ HAP (211) } & Vacuum & -8.946 & -8.946 & -1.116 \\
\hline & Solution & -872.448 & -895.050 & $-6.04310^{-2}$ \\
\hline \multirow[t]{2}{*}{ HAP (310) } & Vacuum & -41.980 & -41.980 & -1.689 \\
\hline & Solution & -875.410 & -895.949 & -0.002 \\
\hline HAP (213) & Vacuum & -43.509 & -43.509 & -1.498 \\
\hline
\end{tabular}




\begin{tabular}{lllll} 
& Solution & -875.434 & -898.487 & $-6.043 .10^{-2}$ \\
\hline HAP (411) & Vacuum & -7.453 & -7.453 & $-6.043 .10^{-2}$ \\
& Solution & -877.948 & -899.456 & $-6.043 .10^{-2}$ \\
\hline HAP (300) & Vacuum & -17.834 & -17.834 & -0.001 \\
& Solution & -875.444 & -898.621 & -0.001 \\
\hline HAP (112) & Vacuum & -19.669 & -19.669 & -0.005 \\
& Solution & -870.181 & -895.483 & $-6.039 .10^{-2}$ \\
\hline Collagen & Vacuum & -109.818 & -109.818 & -1.309 \\
& Solution & -609.236 & -233.996 & -0.913 \\
\hline
\end{tabular}

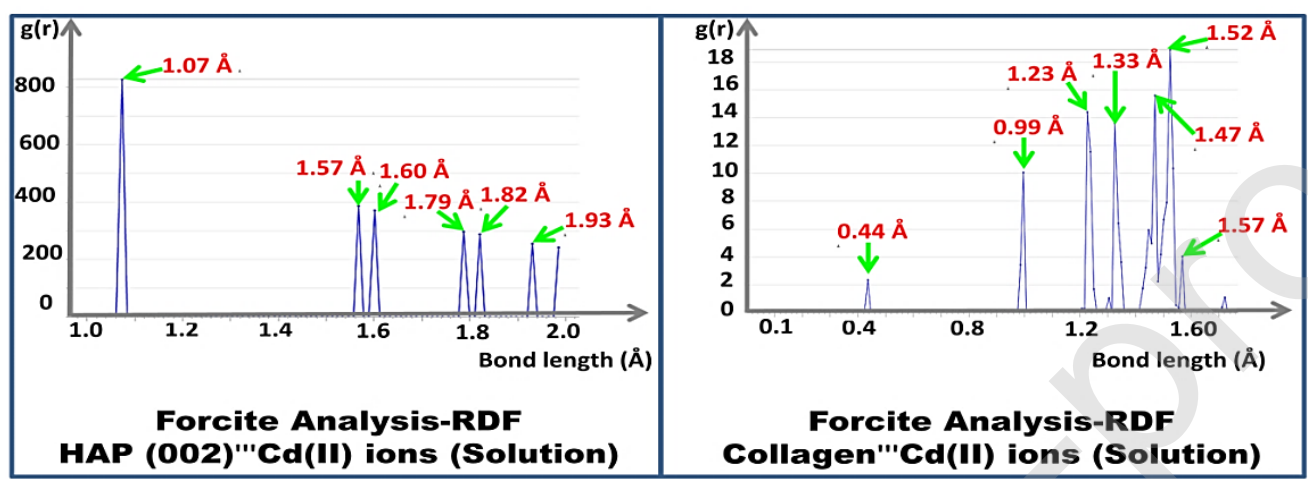

Fig 9. Paired correlation function $\mathrm{g}(\mathrm{r})$ of the $\mathrm{Cd}(\mathrm{II})$ ions/solution/substrate interfaces

\section{Conclusions}

Fish scales of the Sardina pilchardus were found to be a low-cost biosorbent for the removal of cadmium ions from aqueous solutions. This biosorbent showed a good biosorption capacity for $\mathrm{Cd}(+\mathrm{II})$ and gave excellent removal efficiency. At the optimum condition (e.g. contact time, 1h; FS mass, $250 \mathrm{mg}$; cadmium concentration, $75 \mathrm{mg} \mathrm{L}^{-1}$; V, $50 \mathrm{~mL} ; \mathrm{pH}, 3$ and temperature, $298 \mathrm{~K}), 88.20 \%$ of cadmium ions was removed. The kinetic study showed that the biosorption phenomenon obeys the pseudo-second order. In addition, the feasibility of biosorption was confirmed by a good fitting with Langmuir isotherm model.

A full factorial design was used to describe the process by a model of first order, by controlling the principal factors affecting the treatment, namely initial $\mathrm{pH}$, the dose of $\mathrm{Cd}^{2+}$ and the weight of adsorbent. The analysis of variance tests indicates a high significance of the model chosen with high values of the Fisher report. Elsewhere, the results of model 
validation show that the model proposed agrees with experimental results with high values of the coefficient of determination $\mathrm{R}^{2}$.

MC calculations were achieved under two environments: in vacuum (60Cd(II)/HAP or Collagen) and in acidic solution (60Cd(II), $200 \mathrm{H}_{2} \mathrm{O}, 20 \mathrm{H}_{3} \mathrm{O}^{+}, 5 \mathrm{SO}_{4}^{2-} / \mathrm{HAP}$ or Collagen). The computational results reveal the prominent role of acidic medium to reaching high interaction between $\mathrm{Cd}(\mathrm{II})$ ions and substrate. We mentioned that $\mathrm{Cd}(\mathrm{II})$ ions have a stronger interaction with HAP surfaces than with collagen. Furthermore, it is observed that the Cd(II) ions are more biosorbed onto (002) Miller plan of HAP compared to other Miller plans. In addition, the biosorption process was spontaneous. Pair correlation function $(g(r))$ analysis shows that the adsorption behavior is a chemisorption type.

\section{Credit author statement}

Adil Jaafar: Conceptualization, Investigation, Methodology, Software, Writing - Original Draft, Writing - Review \& Editing, Visualization. André Darchen : Conceptualization, Methodology, Writing - Original Draft, Writing - Review \& Editing. Said El Hamzi : Conceptualization, Methodology, Software, Visualization. Zouhair Lakbaibi : Conceptualization, Methodology, Software, Writing - Original Draft, Validation. Anas Driouich : Methodology, Software, Writing - Original Draft, Visualization., Abdelghani Boussaoud : Supervision. Abdelrani Yaacoubi : Supervision. El Makhfouk Mohammed : Supervision. Mohsine Hachkar : Supervision.

\section{Conflict of interest}

The authors declare that they have no conflict of interest.

\section{Acknowledgment}

The authors would like to thank ENSC of Rennes, CNRS and the Institute of Chemical Sciences of Rennes (France), the Superior School of Technology and Faculty of Sciences Semlalia at Cadi Ayad University (Morocco). 


\section{References}

[1] P.K. Padmavathiamma, L. Li, Phytoremediation technology: hyperaccumulation metals in plants, Water Air Soil Pollut. 184 (2007) 105-126.

[2] S. Babel, T.A. Kurniawan, Low-cost adsorbents for heavy metals uptake from contaminated water: a review, J. Hazard. Mater. B97 (2003) 219-243.

[3] L. Joseph, B.M. Jun, J.R.V. Flora, C.M. Park, Y. Yoon, removal of heavy metals from water sources in the developing world using low-cost materials: A review, Chemosphere, 229 (2019) 142-159.

[4] A. Hass, P. Fine, Sequential selective extraction procedures for the study of heavy metals in soils, sediments and waste materials - a critical review, Critical Reviews Environ. Sci. Technol. 40 (2010) 365-399.

[5] M.K. Uddin, A review on the adsorption of heavy metals by clay minerals, with special focus on the past decade, Chem. Eng. J. 308 (2017) 438-462.

[6] A.E. Burakov, E.V. Galunin, I.V. Burakova, A.E. Kucherova, S. Agarwal, A.G. Tkachev, V.K. Gupta, Adsorption of heavy metals on conventional and nanostructured materials for wastewater treatment purposes: A review, Ecotoxicol. Environ. Safety, 148 (2018) 702-712.

[7] S.S. Fiyadh, M.A. AlSaadi, W.Z. Jaafar, M.K. AlOmar, S.S. Fayaed, N.S. Mohd, L.S. Hin, A. El-Shafic, Review on heavy metal adsorption process by carbon nanotubes, J. Cleaner Production, 230 (2019) 783-793.

[8] M.P. Waalkes, Cadmium carcinogenesis in review, J. Inorg. Biochem. 79 (2000) 241244.

[9] I. Zwolak, The role of selenium in arsenic and cadmium toxicity: An updated review of scientific literature, Biol. Trace Element Res. 193 (2020) 44-63.

[10] M.N. Rana, J. Tangpong, M.M. Rahman, Toxicodynamics of lead, cadmium, mercury and arsenic-induced kidney toxicity and treatment strategy: A mini review, Toxicology Reports 5 (2018) 704-713.

[11] D. Purkayastha, U. Mishra, S. Biswas, A comprehensive review on Cd(II) removal from aqueous solution, J. Water Process Eng. 2 (2014) 105-128.

[12] L. Xu, G. Cao, X. Xu, S. Liu, Z. Duan, C. He, Y. Wang, Q. Huang, Simultaneous removal of cadmium, zinc and manganese using electrocoagulation: Influence of operating parameters and electrolyte nature, J. Environ. Manage. 204 (2017) 394-403.

[13] M. Alameen, N. Majeed, Removal of cadmium from industrial wastewater using electrocoagulation process, J. Engineering 26 (2020) 24-34. 
[14] K. Brahmi, W. Bouguerra, B. Hamrouni, E. Elaloui, M. Loungou, Z. Tlili, Investigation of electrocoagulation reactor design parameters effect on the removal of cadmium from synthetic and phosphate industrial wastewater, Arabian J. Chem. 12 (2019) 1848-1859.

[15] L. Xu, G. Cao, X. Xu, C. He, Y. Wang, Q. Huang, M. Yang, Sulfite assisted rotating disc electrocoagulation on cadmium removal: Parameter optimization and response surface methodology, Sep. Purif. Technol. 195 (2018) 121-129.

[16] H.K. Shahzad, M.A. Hussein, F. Patel, N. Al-Aqeeli, M.A. Atieh, T. Laoui, Synthesis and characterization of alumina-CNT membrane for cadmium removal from aqueous solution, Ceramics International 44 (2018) 17189-17198.

[17] N. Chitpong, S.M. Husson, Polyacid functionalized cellulose nanofiber membranes for removal of heavy metals from impaired waters, J. Membrane Sci. 523 (2017) 418429.

[18] K. Pyrzynska, Removal of cadmium from wastewaters with low-cost adsorbents, J. Environ. Chem. Eng. 7 (2019) 102795, https://doi.org/10.1016/j.jece.2018.11.040

[19] S.K.R. Yadanaparthi, D. Graybill, R. von Wandruszka, Adsorbents for the removal of arsenic, cadmium and lead from contaminated waters, J. Hazard. Mater. 171 (2009) 115.

[20] S. Hokkanen, E. Repo, L.J. Westholm, S. Lou, T. Sainio, M. Sillanpää, Adsorption of $\mathrm{Ni}^{2+}, \mathrm{Cd}^{2+}, \mathrm{PO}_{4}{ }^{3-}$ and $\mathrm{NO}_{3}$ - from aqueous solutions by nanostructured microfibrillated cellulose modified with carbonated hydroxyapatite, Chem. Eng. J. 252 (2014) 64-74.

[21] T.A. Salah, A.M. Mohammad, M.A. Hassan, B.E. El-Anadouli, Development of nano-hydroxyapatite/chitosan composite for cadmium ions removal in wastewater treatment, J. Taiwan Institute Chem. Eng. 45 (2014) 1571-1577.

[22] N. Zayadi, N. Othman, Characterization and optimization of heavy metals biosorption by fish scales, Advanced Mater. Res. 795 (2013) 260-265.

[23] O.A.A. Eletta, J.O. Ighalo, A review of fish scales as a source of biosorbent for the removal of pollutants from industrial effluents, USEP J. Res. Information Civil Eng. 16 (2019) 2479-2510.

[24] K. Jayathilakan, K. Sultana, K. Radhakrishna, A.S. Bawa, Utilization of byproducts and waste materials from meat, poultry and fish processing industries: A review, J. Food Sci. Technol. 49 (2012) 278-293.

[25] I.G. Shaikhiev, N.V. Kraysman, S.V. Sverguzova, S.E. Spesivtseva, A.N. Yarothckina, Fish scales as a biosorbent of pollutants from wastewaters and natural waters (a literature review), Biointerface Res. Appl. Chem. 10 (2020) 6893-6905. 
[26] J.O. Ighalo, O.A.A. Eletta, Recent advances in the biosorption of pollutants by fish scales: a mini review, Chem. Eng. Commun. (2020), https://doi.org/10.1080/00986445.2020.1771322

[27] K.O. Moura, E.F.S. Vieira, A.R. Cestari, The use of solution microcalorimetry to evaluate chemically modified fish scales as a viable adsorbent for heavy metals, J. Therm. Anal. Calorim. 107 (2012) 999-1005.

[28] A.H. El-Sheikh, J.A. Swelleh, Sorption of trace metals on fish scales and application for lead and cadmium pre-concentration with flame atomic absorption determination, Jordan J. Chem. 3 (2008) 87-97.

[29] K. Prabu, S. Shankarlal, E. Natarajan, A biosorption of heavy metal ions from aqueous solutions using fish scale (Catla catla), World J. Fish Marine Sci. 4 (2012) 73 77.

[30] J.F. Villanueva-Espinosa, M. Hernandez-Esparza, F.A. Ruiz-Trevino, Adsorptive properties of fish scales of Oreochromis Niloticus (Mojarra Tilapia) for metallic ion removal from waste water, Ind. Eng. Chem. Res. 40 (2001) 3563-3569.

[31] Z.J. Bajic, V.R. Djokic, Z.S. Velickovic, M.M. Vuruna, M.D. Ristic, N.B. Issa, A.D. Marinkovic, Equilibrium, kinetic and thermodynamic studies on removal of $\mathrm{Cd}(\mathrm{II})$, $\mathrm{Pb}(\mathrm{II})$ and $\mathrm{As}(\mathrm{V})$ from wastewater using carp (Cyprinus carpio) scales, Digest J. Nanomater. Biostructures 8 (2013) 1581-1590.

[32] J.D. Kechagias, K.E. Aslani, N.A. Fountas, N.M. Vaxevanidis, D.E. Manolakos, A comparative investigation of Taguchi and full factorial design for machinability prediction in turning of a titanium alloy, Measurement 151 (2019), https://doi.org/10.1016/j.measurement.2019.107213

[33] S.G. Muntean, M.A. Nistor, R. Ianoș, C. Păcurariu, A. Căpraru, V.A. Surdu, Combustion synthesis of $\mathrm{Fe}_{3} \mathrm{O}_{4} / \mathrm{Ag} / \mathrm{C}$ nanocomposite and application for dyes removal from multicomponent systems, Appl. Surf. Sci. 481 (2019) 825-837.

[34] N. Barka, M. Abdennouri, A. Boussaoud, M. El Makhfouk, Biosorption characteristics of Cadmium (II) onto Scolymus hispanicus L. as low-cost natural biosorbent, Desalination. 258 (2010) 66-71.

[35] C. Lafarge, M. Bitar, L. El Hosry, P. Cayot, E. Bou-Marouna, Comparison of molecularly imprinted polymers (MIP) and sol-gel molecularly imprinted silica (MIS) for fungicide in a hydro alcoholic solution, Mater. Today Commun. 24 (2020), https://doi.org/10.1016/j.mtcomm.2020.101157

[36] I. Langmuir, The adsorption of gases on plane surfaces of glass, mica, and platinum, J. Am. Chem. Soc. 40 (1918) 1361-1368. 
[37] F. Gimbert, N. Morin-Crini, F. Renault, P.M. Badot, G. Crini, Adsorption isotherm models for dye removal by cationized starch-based material in a single component, J. Hazard. Mater. 157 (2008) 34-46.

[38] A. Maleki, B. Hayati, M. Naghizadeh, S.W. Joo, Adsorption of hexavalent chromium by metal organic frameworks from aqueous solution. J. Ind. Eng. Chem. 28 (2015) 211216.

[39] H.M.F. Freundlich, Over the adsorption in solution, J. Phys. Chem. 5 (1906) 385-470.

[40] Y. Zheng, J. Liu, B. Cheng, W. You, W. Ho, H. Tang, Hierarchical porous $\mathrm{Al}_{2} \mathrm{O}_{3} @ \mathrm{ZnO}$ core-shell microfibres with excellent adsorption affinity for Congo red molecule. Appl. Surf. Sci. 473 (2019) 251-260.

[41] S. Yu, X. Wang, H. Pang, R. Zhang, W. Song, D. Fu, T. Hayat, X. Wang, Boron nitride-based materials for the removal of pollutants from aqueous solutions: a review. Chem. Eng. J. 333 (2018) 343-360.

[42] G.E.P. Box, W.G. Hunter, J.S. Hunter, Statistics for Experimenters: An Introduction to Design, Data Analysis, and Model Building, John Wiley \& Sons, New York, 1978. [43] JMP Version 11: Using JMP (2013) SAS Institute, Cary, NC.

[44] N. Metropolis, A.W. Rosenbluth, M.N. Rosenbluth, A.H. Teller, E. Teller, Equation of state calculations by fast computing machines, J. Chem. Phys. 21 (1953) 1087-1092.

[45] Materials Studio version 8.0 (2016) Accelrys Software Inc, San Diego.

[46] M. C. Erat, D. A. Slatter, E. D. Lowe, C. J. Millard, R. W. Farndale, I. D. Campbell, I. Vakonakis, Identification and structural analysis of type I collagen sites in complex with fibronectin fragments, PNAS. 106 (2009) 4195-4200.

[47] H. Sun, COMPASS: An ab initio force-field optimized for condensed-phase applications - Overview with details on alkane and benzene compounds, J. Phys. Chem. B. 102 (1998) 7338-7364.

[48] X. Lin, R.C. Burns, G.A. Lawrance, Heavy metals in wastewater: the effect of electrolyte composition on the precipitation of $\mathrm{Cd}(\mathrm{II})$ using lime and magnesia, Water Air Soil Pollut. 165 (2005) 131-152.

[49] B. Das, N.K. Mondal, Calcareous soil as a new adsorbent to remove lead from aqueous solution: equilibrium, kinetic and thermodynamic study, Universal J. Environ. Res. Technol. 1 (2011) 515-530.

[50] A.A. Lewinsky, Hazardous materials and wastewater: treatment, removal and analysis, Nova Science, New York, 2007, pp. 375.

[51] S. Ran-ran, Y. Liang-guo, Y. Kun, H. Yuan-feng, D. Bin, Adsorption of Cd(II) by $\mathrm{Mg}-\mathrm{Al}-\mathrm{CO}_{3}$ - and magnetic $\mathrm{Fe}_{3} \mathrm{O}_{4} / \mathrm{Mg}-\mathrm{Al}-\mathrm{CO}_{3}$-layered double hydroxides: Kinetic, 
isothermal, thermodynamic and mechanistic studies, J. Hazard. Mater. 299 (2015) 4249.

[52] A. Verma, S. Kumar, S. Kumar, Statistical modeling, equilibrium and kinetic studies of cadmium ions biosorption from aqueous solution using S. filipendula, J. Environ. Chem. Eng. 5 (2017) 2290-2304

[53] G. Mimanne, K. Benhabib, A. Benghalem, S. Taleb, Etude de l'adsorption des métaux lourds $(\mathrm{Pb}$ et $\mathrm{Cd})$ en solution aqueuse sur charbon actif et montmorillonite sodée de l'Ouest Algérien, J. Mater. Environ. Sci. 5 (2014) 1298-1307.

[54] F. Noli, E. Kapashi, M. Kapnisti, Biosorption of uranium and cadmium using sorbents based on Aloe vera wastes, J. Environ. Chem. Eng. 7 (2019), https://doi.org/10.1016/j.jece.2019.102985

[55] J.P. Aristizabal, R. Giraldo, J. Mateu, Analysis of variance for spatially correlated functional data: Application to brain data, Spatial Statistics. 32 (2019), https://doi.org/10.1016/j.spasta.2019.100381

[56] A. Driouich, S.E.A. El-Hassani, H. Labjar, S. Kassbi, T.N. Kambuyi, O. Britel, B. Sallek, K. Digua, R. Chroqui, H. Chaair, Modeling and optimizing synthesis of irreversible gel by sol-gel using experimental design. Phosphorus, Sulfur, and Silicon and the Related Elements, 195 (2020) 50-59.

[57] A. Jaafar, A. Driouich, Z. Lakbaibi, H. Ben El Ayouchia, K. Azzaoui, A. Boussaoud, S. Jodeh, Central composite design for the optimization of Basic Red V degradation in aqueous solution using Fenton reaction, Desalination Water Treatment, 158 (2019) 364 371.

[58] F El-Hajjaji, M. Messali, A. Aljuhani, M.R. Aouad, B. Hammouti, M.E. Belghiti, D.S. Chauhan, M.A. Quraishi, Pyridazinium-based ionic liquids as novel and green corrosion inhibitors of carbon steel in acid medium: Electrochemical and molecular dynamics simulation studies, J. Mol. Liq. 249 (2018) 997-1008.

[59] M Schümann, J. Morich, S. Günther, S. Odenbach, The evaluation of anisotropic particle structures of magnetorheological elastomers by means of pair correlation function, J. Magnetism Magnetic Mater. 502 (2020) 166537, https://doi.org/10.1016/j.jmmm.2020.166537

[60] Z. Zhang, N.C. Tian, X.D. Huang, W. Shang, L. Wu, Synergistic inhibition of carbon steel corrosion in $0.5 \mathrm{M} \mathrm{HCl}$ solution by indigo carmine and some cationic organic compounds: experimental and theoretical studies, RSC Adv. 6 (2016) 22250-22268. 
[61] M. Aliabadi, M. Irani, J. Ismaeili, S. Najafzadeh, Design and evaluation of chitosan/hydroxyapatite composite nanofiber membrane for the removal of heavy metal ions from aqueous solution, J. Taiwan Institute Chem. Eng. 45 (2014) 518-526. 